\title{
Light intensity on two mangrove species as an indicator of regeneration in a disturbed forest in Campeche, Mexico
}

\author{
J. J. Guerra-Santos, J. A. Méndez-Sánchez, Á. Alderete-Chávez, \\ N. de la Cruz-Landero \& E. del Carmen Guevara-Carrió \\ Centro de Investigación de Ciencias Ambientales, \\ Universidad Autónoma del Carmen, México
}

\begin{abstract}
The seed germination of Laguncularia racemosa and Avicennia germinans, was assessed to know the growth of seedlings under controlled conditions at different intensities of shadow $(0,35,50$ and $75 \%$ darkness $)$. Previously selected seeds were used from random trees located in Ciudad del Carmen Campeche. $L$. racemosa shows an average value in the seed weight of $0.69 \mathrm{~g}, 2.26 \mathrm{~cm}$ length and $1.19 \mathrm{~cm}$ width, for $A$. germinans, the average seed weight was $3.79 \mathrm{~g}$, $3.26 \mathrm{~cm}$ long and $2.20 \mathrm{~cm}$ wide. L. racemosa germination began at 11 days, while in $A$. germinans, it began at 9 days. At the end of the evaluation, the germination percentages were $22.62 \%$ for $A$. germinans and $65 \%$ for L. racemosa. Moreover, the results indicated that at increasing darkness levels for both species; stem length can increase, compared with the control that was full sunlight. Apparently, the seeds of A. germinans do not tolerate high light intensities; a trend also observed in seedlings, because they show a high rate of mortality and consequently, a lower germination percentage compared to L. racemosa. The results can be useful to propose regeneration activities in natural mangroves of the tropical area of Mexico.
\end{abstract}

Keywords: red mangrove, white mangrove, germination.

\section{Introduction}

Mangroves are very rich, diverse and complex ecosystems occurring among coastal, estuarine and marine systems along tropical and subtropical lands 
worldwide. They provide services including protection against flooding, nutrient production, organic matter incorporation, sediment control, temporal and permanent refuge for high value species, place to allow a higher index of biodiversity, and stabilizers as well as protection of the coast [1]. Mangroves were recognized by the General Assembly of the United Nations as ecosystems of high economic, social, and ecological importance [2]. In Mexico, mangroves are distributed along the coast on more than $10,000 \mathrm{~km}$ of the Mexican littoral [3]. According to some estimations, mangroves in Mexico occur on about $9,140 \mathrm{~km}^{2}$ [4]. And the most important species are Rhizophora mangle L. (Red mangrove), Laguncularia racemosa (White mangrove), Avicennia germinans (Black mangrove), Conocarpus erectus L. (Button mangrove), and only in the state of Chiapas, Rhizophora harrisonii Leechm and Avicennia bicolor L. [5]. Mexico is the second place of distribution and extension of mangroves in America, mangroves occurs in 17 states of the country, in the Yucatan Peninsula has the $55 \%$ of the total extension, followed by the North Pacific region with about 24.5\%; the Gulf of Mexico with 11\%, and South Pacific region, 8.6\% [6]. Among the Mexican states, Campeche has $25.4 \%$ of mangroves and $10.7 \%$ belongs to Laguna de Términos (Terminos Lagoon) [4].

Because they are along the coast can be affected by natural and anthropogenic impacts [7]. Some of the natural factors that contributed in degradation and loosed of mangroves are cyclones [8], as well as geomorphologic processes, reduction in water discharge from rivers, changes in tide regime, dry, and high rates of sedimentation, than can cause changes in salinity, fertility and anoxia [9]. On the main human alteration are loose of surface covered by mangroves because they were changed to establish cattle and shrimp production, and agriculture, illegal forest harvest, contamination by black waters and crop land washed, as well as urbanization that includes touristic recreation and construction of paths, channels and dicks [10]. The line coast degradation and mangrove destruction ( $25 \%$ in 10 years) is evident and is of world concern then is necessary to improve the restoration of these ecosystems on the basis of ecological criteria [11].

The most productive mangroves are along the deltaic coast and estuaries that show fine mud composed by silt, clay, and a very important quantity of organic matter. Anaerobic sediments do not represent any problem to mangroves [12]. The soils masses in wetlands composed by mangroves have physical, chemical, and biological properties almost always constant such as soluble mineral content and $\mathrm{pH}$ among others [13]. Mangrove regeneration is a process that can be explore considering soil characteristics, canopy aperture (light intensity), the tide effect and the high degree of salinity as factors that can be affect the seed germination and the initial establishment of seedlings [14]. To ensure the conservation and production of these ecosystems is necessary to know the seedlings growth performance due to that the most important species for this environment are A. germinans and L. racemosa [15].

Seedling survival and growth are influenced by physical-chemical stress [16], specifically light intensity, due the mangrove trees during their growth being exposed to high light intensities and they are considered as intolerant species 
[17]; the photosynthetic rate has the tendency to be stabilized with low intensity light [18], and they can show better growth with significantly lower levels of irradiation than trees growing with direct light [19].

This work was developed in order to know the germination and initial growth of Laguncularia recemosa and Avicennia germinans seedlings under different light intensities $(35 \%, 50 \%$ and $75 \%)$, to evaluate individual characteristics on both species affected by these light intensities and then to know which one has better germination to use in regeneration programs.

\section{Materials and methods}

\subsection{Site description}

The study was conducted in a site located within the Botanical Garden of the Autonomous University of Carmen Island (Lat. $18^{\circ} 38^{\prime} 36^{\prime \prime} \mathrm{N}$, Long. 91 $41^{\circ} 51^{\prime \prime}$ W, elev. 2 masl) on the southwest edge of Carmen City in Campeche, Mexico (Fig. 1). The geomorphology of the area consists of wetlands and floodplains at elevations between 0 and $20 \mathrm{~m}$. The soils of the region are characterized by heavy clay with high fertility and are associated with predominant vegetation of mangrove forest as Rhizophora mangle, Avicennia germinans, Laguncularia racemosa, and Conocarpus erectus [20].

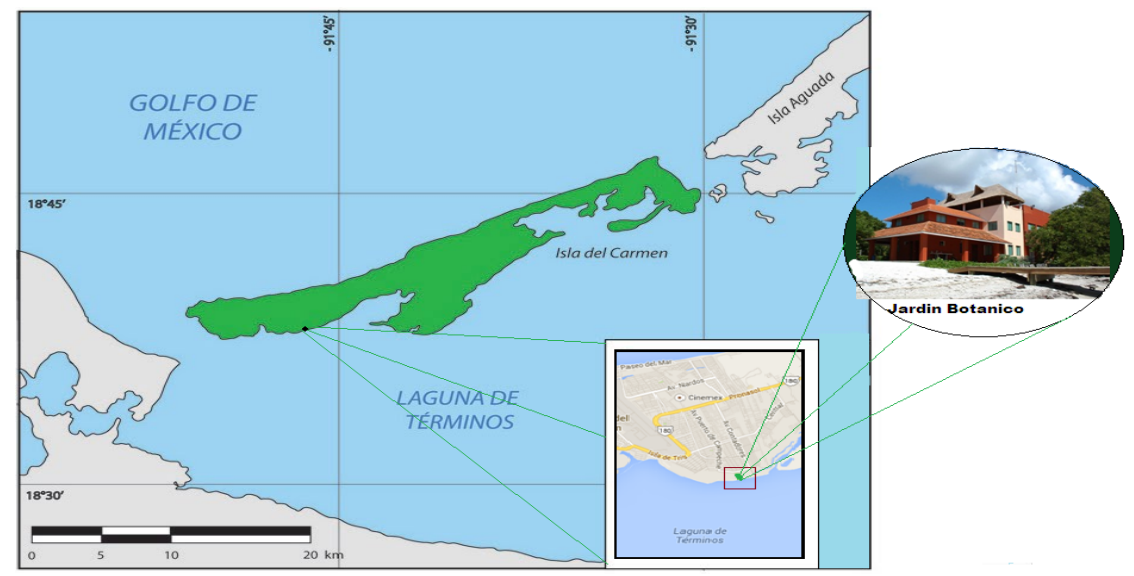

Figure 1: Site location.

\subsection{Seed collection}

Seed collection was made from September to October 2013; hand collection directly from the ground, checking color, texture, size, and shape of the seeds, in a ratio of no more than 2.5 meters from the progenitor tree and taking the seeds recently released in the fructification stage and without mechanical damages. A total of 800 seeds were collected of each mangrove species, considering their 
optimum point of maturity, characterized by the yellow color of the seed surface. Then 100 seeds were measured and weighed. The size of a single seed was measured using a Digital Vernier Pretul ${ }^{\text {TM }}$ and the weight was obtained using an analytical balance.

\subsection{Treatments}

Both species were seeded on January 2013 and were recorded until May 2013. Three light intensities using different size mesh, to obtain T1:35, T2:50, and $\mathrm{T} 3: 75 \%$ of darkness were used to establish the treatments and the control without mesh. Seed germination was observed daily. To be sure that the light intensity was the same during the experiment a photometer Phytotronics, Inc. L396768 was used. The temperature and relative humidity also were measured with a digital thermometer. Statistical analyses were made to compare the light intensity, seed size and weight as time of germination between the two species. Analyses of variance were performed using the statistical software SPPS with significance level $\alpha 0.05$.

\section{Results and discussion}

There are significant differences between the seeds of each species in weight, size and shape $(\mathrm{p} \leq 0.05)$, the seeds of Avicennia germinans are yellowish and tiny while Laguncularia racemosa are dark green and flattened. The germination started nine days after been seeded in A germinans with a total of $22.6 \%$ of germination and 11 days in L. racemosa with $65 \%$ of germination.

\subsection{Germination}

There are significant differences $(\mathrm{p} \leq 0.05)$, in $A$. germinans in germination, control showed less germination than the treatments under darkness (Figure 2A) while in L. racemosa control showed better percentage of germination than the treatments (Figure 2B). A. germinans does not have the capability of being regenerated under dark even a little darkness [21]; in this study seedlings can grow under darkness

A

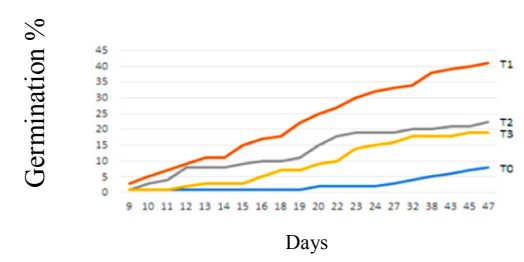

B

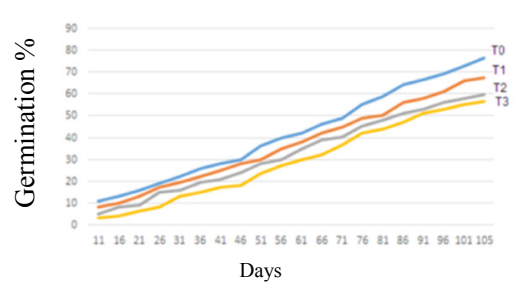

Figure 2: Rate of germination for mangrove species after seeded, showing the increase in number of germinated seeds throughout time. A. Laguncularia racemosa; B. Avicennia germinans. 


\subsection{Increase in growth}

Regarding the growth in height $L$. racemosa all treatments obtain good increase $\mathrm{T} 1,18.6 \mathrm{~cm}$; T2, $19.7 \mathrm{~cm}$; and T3, 19.5; there is no significant difference $(\mathrm{p} \leq 0.05)$, with control plants (Figure $3 \mathrm{~A})$. At the beginning of the study A. germinans showed significant differences $(\mathrm{p} \leq 0.05)$, but at the end the growth of all treatments including control plants showed the same increase in height (Figure 3B). Seedlings with high direct light grew less than those under darkness; but in contrast, in the Philippines seedlings are not affected by growing in open stands during the rainy season [22].

A

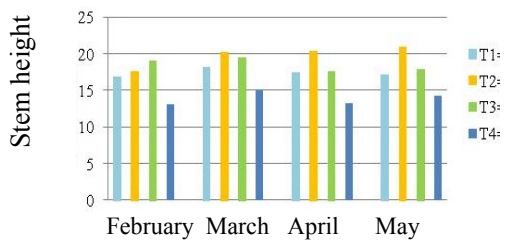

B

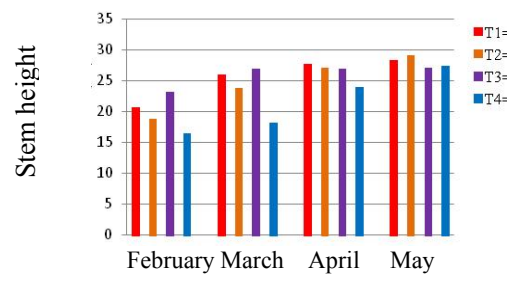

Figure 3: Growth in stem length for mangrove species after seeded. A. Laguncularia racemosa; B. Avicennia germinans.

\subsection{Diameter}

There are significant differences ( $\mathrm{p} \leq 0.05)$, in $L$ racemosa, in diameter increase, it was observed at the end of the study that the control had the lower values than the treatments (Figure 4A). Similar results were found for A. germinans the T1 had the higher diameter value and the control had significant differences $(\mathrm{p} \leq 0.05)$, with the treatments (Figure 4B). A. germinans seedlings can die when grown under closed stands with lower quantities of light [23].

A

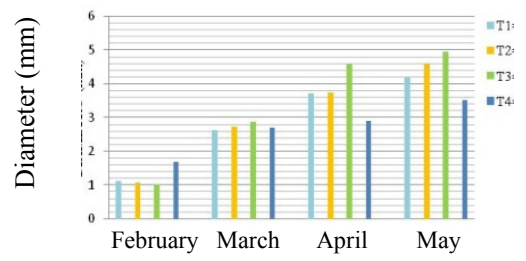

B

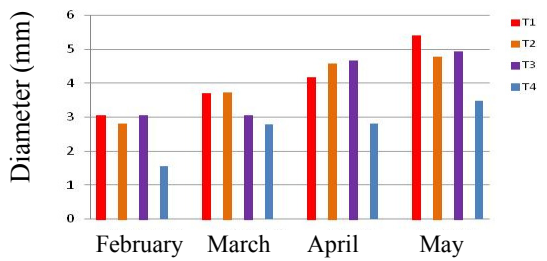

Figure 4: Growth in diameter for mangrove species after seeded. A. Laguncularia racemosa; B. Avicennia germinans. 


\subsection{Roots}

There are no significant differences $(\mathrm{p} \leq 0.05)$, in the number of roots in $L$. racemosa, while in $A$. germinans control plants showed the higher value in number of roots. About the root length there are no significant differences $(\mathrm{p} \leq 0.05)$, in $L$. racemosa, while in A. germinans there are significant differences $(\mathrm{p} \leq 0.05)$, the control showed the less root length. Under a high quantity of light there is a great root production in mangroves, on extreme darkness the number of roots seems to be low, this results has been previously reported [24]; better root grow can be occurs with moderate darkness during the initial stages of seedling growth

\subsection{Leaves}

There are no significant differences $(\mathrm{p} \leq 0.05)$, of $L$. racemosa in the number of leaves in all treatments compared with the control at the end of the recorded data (Figure 5A), same situation in A. germinans, there are significant differences $(\mathrm{p} \leq 0.05)$, at the first stages of growth, the control showed more quantity of leaves than the treatments, but at the end of the trial no significant differences were found (Figure 5B). Under darkness was more increase in stem growth than the number of leaves in both studied species; but more leave occurrence could be associated to soil substrate [25].

A

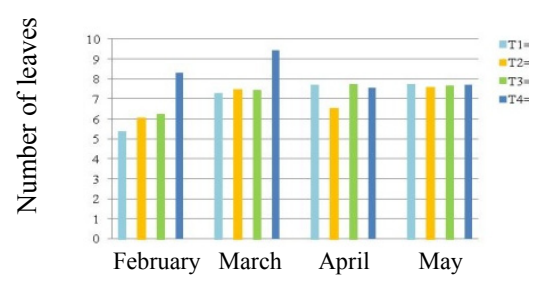

B

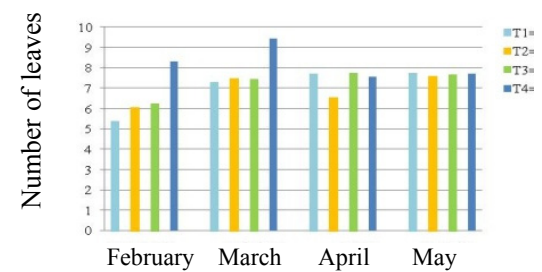

Figure 5: Number of leaves for mangrove species after seeded. A. Laguncularia racemosa; B. Avicennia germinans.

It is very important to consider that seedlings can show high mortality under nursery conditions at least in the first year [26]. In this study it was possible to know conditions to improve survival of the seedlings

According to the results in any mangrove restoration plan, the condition of trees to grow under darkness will be considered mainly in the first stages of stand establishment

\section{Conclusions}

The growth of seedlings can be influenced by the different rates of darkness. With more darkness, the growth in length increased. With favorable conditions, the plants also can increase in size and number of leaves. 
The more rate of darkness also increase the number of roots. Both species do not tolerate high light intensity, but they can obtain better growth with some darkness conditions

Laguncularia racemosa has more survival possibilities and it can be used as a very potential specie in restoration programs after that Avicennia germinans can be established in stands for natural regeneration.

\section{References}

[1] Spalding, M, World Atlas of Mangroves. Earthscan Ltd. 210 p., 2010.

[2] Field, C, Charter for mangroves. In: Yáñez-Ancibia, A. and A. LaraDomínguez (eds.). Ecosistemas de manglar en América tropical. Instituto de Ecología, A. C. México, UICN/HORMA, Costa Rica, NOAA/NMFS Silver Spring MD USA. 380p., 1999.

[3] Flores-Verdugo, F.J. Algunos aspectos sobre la ecología, uso e importancia de los ecosistemas de manglar. En: J. de la Rosa-Vélez and F. González-Farías (eds.). Temas de oceanografía biológica en México. Universidad Autónoma de Baja California, México, pp. 21-56, 1989.

[4] FAO (Food and Agriculture Organization of the United Nations), Evaluación de los recursos forestales mundiales 2005. Informe Nacional. México. Informe FRA2005/189. (Roma, Italia: Departamento Forestal, Organización de las Naciones Unidas para la Agricultura y la Alimentación) 2005.

[5] Nettel, A, Dodd, R, Afzal-Rrafii, Z. Y. Tovilla-Hernández, C., Genetic diversity enhanced by ancient introgression and secondary contact in East Pacific black mangroves. Molecular Ecology, 17, pp. 2680-2690, 2008.

[6] CONABIO. Manglares de México. Comisión Nacional para el Conocimiento y Uso de la Biodiversidad, México, D.F., México, 2008.

[7] Alongi, D. M. The energetics of mangrove forest. (Netherlands: Springer). 216 p., 2009.

[8] Kovacs, J. M., Flores, F., Wang, J. and Aspden, L. P. Estimating leaf area index of a degraded mangrove forest using high spatial resolution satellite imagery. Aquatic Botany, 80, pp. 13-22, 2004.

[9] Osborne, P. L., Tropical ecosystems and ecological concepts. Cambridge University Press. pp. 132-136, 2000.

[10] Jiménez, J. A., Lugo, A. E. and Cintron G. Tree mortality in mangrove forest. Biotropica 17 (3), pp. 177-185, 1985.

[11] Agraz-Hernández, C., Osti Sáenz, J., Jiménez Zacarías, J., García Zaragoza, C., Arana Lezama, R., Chan Canul, E., González Duran, L. and Palomo Rodríguez, A. Guía técnica: Criterios para la restauración del mangle. Universidad Autónoma de Campeche, Comisión Federal de Electricidad, Comisión Nacional Forestal. 132 p., 2007.

[12] Domínguez, D. M. Evaluación del crecimiento de plántulas de Rhizophora mangle L. bajo diferentes condiciones de sustrato $e$ intensidad de luz. Tesis de maestría en Ciencias. Colegio de Posgraduados. Programa Forestal. 102p., 1994. 
[13] Seoánez, C. M. Ingeniería del medio ambiente (Aguas residuales: Tratamientos por humedales artificiales. Fundamentos científicos, Tecnologías, Diseño. Ediciones Mundo-Prensa. España. 254 p., 1990.

[14] Sobrado M.A. Influence of external salinity on the osmolality of xylem sap, leaf tissue and leaf gland secretion of the mangrove Laguncularia racemosa (L.) Gaertn. Trees 18: pp. 422-427, 2004.

[15] Acosta-Velázquez J., Rodríguez-Zúñiga, M.T., Cerdeira-Estrada, S., Cruz, I., Ressl, R. and Ascensión, M. Los manglares de México: estado actual y establecimiento de un programa de monitoreo a largo plazo: 1a. etapa, Informe del Proyecto DQ056, CONABIO, 69 p., México, 2007.

[16] Krauss, K. W., Lovelock, C. E., McKee K. L., López-Hoffman L., Ewe S. M. L. and Sousa W. P. Environmental drivers in mangrove establishment and early development: A review. Aquatic Bot. 89: pp. 105-127, 2008.

[17] Janzen, D. H. Mangroves: Where's the Understory. J. Trop. Ecol. 1: 89, 1985.

[18] Kathiresan, K. and Moorthy, P. Influence of different irradiance on growth and photosynthetic characteristics in seedlings of Rhizophora species. Photosynthetica 29: pp. 143-146, 1993.

[19] McGuinness, K. A. Dispersal, establishment and survival of Ceriops tagal propagules in a north Australian mangrove forest. Oecologia 109: pp. 8087, 1997.

[20] CONANP (Comisión Nacional de Áreas Naturales Protegidas). Áreas Naturales Protegidas de México. México, D.F. 64 p., 2000.

[21] Pegg, K. G., Guillespie, N. C. and Forsbers, L. I. Phytophtora sp. associated with mangrove death in central coast Queensland. Australian Plant Pathology 9(3), pp. 6-7, 1980.

[22] PCARRD, D. O. The Philippines recommends for mangrove production and harvest. Philippines Recommends Series No. 74. Manila, Department of Environment and Natural Resources, 1991.

[23] Jiménez, J. A. Laguncularia racemosa (L.) Gaertn. F. White mangrove. SO- ITF- SM 3. New Orleans, LA: U.S. Department of Agriculture, Forest Service, Southern Forest Experimental Station. 64 p., 2004.

[24] Smith, S. M. and Lee D. W. Effects of light quantity and quality on early seedling development in the red mangrove, Rhizophora mangle L. Bulletin of Marine Science 65(3): pp. 795-806, 1999.

[25] Zuluaga, S. Observaciones fitoecológicas en el Darién colombiano. PérezArbelaezia 1 (4-5): pp. 85-145, 1999.

[26] Davis, J. H. The ecology and geologic role of mangroves in Florida. Papers of the Tortugas Laboratory (Carnegie Institution). 32: pp. 303-412, 1940. 